\title{
Apricot and pumpkin oils reduce plasma cholesterol and triacylglycerol concentrations in rats fed a high-fat diet
}

\author{
By Mohamed F. Ramadan ${ }^{1,2^{\star}}$, R. Zayed ${ }^{3}$, M.Abozid $^{4}$ and M. M. S. Asker ${ }^{5}$
}

\author{
${ }^{1}$ Agricultural Biochemistry Department, Faculty of Agriculture, Zagazig University, 44519 Zagazig, Egypt. \\ ${ }^{2}$ Chair of Engineer Abdullah Ahmad Baqshan for Bee Research, College of Food and Agricultural Sciences, \\ King Saud University, Riyadh 11451, Kingdom of Saudi Arabia. \\ ${ }^{3}$ Pharmacognosy Department, Faculty of Pharmacy, Zagazig University, 44519 Zagazig, Egypt. \\ ${ }^{4}$ Biochemistry Department, Faculty of Agriculture, Menofia University, Egypt. \\ ${ }^{5}$ Microbial Biotechnology Department, National Research Center, Dokki 12622, Cairo, Egypt \\ (Corresponding author: hassanienmohamed@yahoo.com mframadan@zu.edu.eg)
}

\section{RESUMEN}

Aceites de albaricoque y calabaza reducen las concentraciones de colesterol y de triglicéridos en plasma en ratas alimentadas con una dieta rica en grasas.

Las semillas oleaginosas no convencionales están siendo consideradas debido a que sus componentes tienen propiedades químicas únicas y pueden aumentar la oferta de los aceites comestibles. El propósito del presente estudio fue investigar el efecto de los aceites de semilla de albaricoque (AO) y de calabaza (PO) sobre los perfiles de lípidos y las funciones del hígado de ratas alimentadas con una dieta rica en grasas. Las dietas ricas en grasas dan lugar a grandes alteraciones en el perfil de lípidos del plasma y en las funciones del hígado. Veinticuatro ratas albinas machos, se utilizaron durante un periodo superior a 28 días. Los animales fueron divididos en 4 grupos, en donde el primer grupo representa el control negativo, alimentados con dieta basal, mientras que el grupo 2 recibió una dieta rica en grasas para servir como grupo con hipercolesterolemia (control positivo). Otros dos grupos se alimentaron con una dieta rica en grasas suplementada con $\mathrm{AO}$ y $\mathrm{PO}$. El grupo 3 se trató diariamente con $\mathrm{AO}(1 \mathrm{~g} / \mathrm{kg}$ peso corporal), mientras que el grupo 4 fué tratado con PO $(1 \mathrm{~g} / \mathrm{kg}$ peso corporal). El perfil de lípidos del plasma y las funciones del hígado en los diferentes grupos fue determinado después de 14 y 28 días. Las ratas de los grupos tratados (AO y $\mathrm{PO}$ ) mostraron niveles significativamente menores de colesterol total (CT), triglicéridos totales (TG), colesterol de lipoproteínas de baja densidad (LDLC), y actividades alanina-aminotransferasa (ALT) y aspartato aminotransferasa (AST), así como altos niveles de lipoproteína de alta densidad-colesterol (HDL-C) y proteína total en comparación con el grupo con hipercolesterolemia. Se puede concluir que los $\mathrm{OA}$ y de $\mathrm{PO}$ en estudio son útiles para el tratamiento de la hipercolesterolemia.

PALABRAS CLAVE: Aceite de semilla de albaricoque Aceite de semilla de calabaza - Ácidos grasos - Colesterol - HDL-colesterol - Hipercolesterolemia - LDL-colesterol Poliinsaturados.

\section{SUMMARY}

Apricot and pumpkin oils reduce plasma cholesterol and triacylglycerol concentrations in rats fed a high-fat diet.

Non-conventional oilseeds are being taken into greater consideration because their constituents have unique chemical properties and may increase the supply of edible oils. The purpose of the present study was to investigate the effect of apricot kernel oil (AO) and pumpkin kernel oil (PO) on the lipid profiles and liver functions of rats fed high fat diets. The high fat diet resulted in great alterations in plasma lipid profiles and liver functions. Twenty-four male albino rats were used over a 28 day period. The animals were divided into 4 groups, where group 1 represents the negative control which were a fed basal diet, while group 2 received a high fat diet to serve as the hypercholesterolemic group (positive control). The other two groups were given a high fat diet supplemented with $A O$ and PO. Group 3 was treated daily with $A O(1 \mathrm{~g} / \mathrm{Kg}$ body weight), while group 4 was treated with PO (1 $/ \mathrm{Kg}$ body weight). The plasma lipid profile and liver functions in the different groups were determined after 14 and 28 days. The rats in the treated groups (AO and $\mathrm{PO}$ ) showed significantly lower levels of total cholesterol (TC), total triglycerides (TG), low density lipoprotein-cholesterol (LDL-C), alanine-aminotransferase (ALT) and aspartateaminotransferase (AST) activities as well as high levels of high density lipoprotein-cholesterol (HDL-C) and total protein in comparison with the hypercholesterolemic group. It could be concluded that $\mathrm{AO}$ and $\mathrm{PO}$ under study are useful for the treatment of hypercholesterolemia.

KEY-WORDS: Apricot seed oil - Cholesterol - Fatty acids - HDL-cholesterol - Hypercholesterolemia - LDL-cholesterol Polyunsaturated - Pumpkin seed oil.

\section{INTRODUCTION}

Elevated blood levels of total cholesterol and LDL-C are established risk factors for the development of coronary heart disease (CHD), the major health problem in developed countries (Law, 1999; Muldoon et al., 2001). A large majority of epidemiological studies have demonstrated that elevated plasma triglycerides and/or reduced plasma HDL-C concentrations are associated with increased cardiovascular risk (Poli et al., 2008; $\mathrm{Da}$ Luz et al., 2008). Diet plays a major role in reducing the risk of CHD. Dietary fat can alter blood composition; serum lipoprotein levels are subjected to change by including added fat in the diet (Hermier and Dillon, 1992). Generally, saturated 
fatty acids increased the levels of LDL which are very atherogenic, partly by reducing the receptormediated uptake; whereas HDL provides protection against atherosis through the transportation of cholesterol from tissue to liver for conversion to bile acids and excretion (Eisenberg, 1984; Grundy, 1989). This has led to the search for specific foods and food components that may help to improve the serum lipoprotein profile (Danielle et al., 2002).

Diets high in monounsaturated fatty acids (MUFA) and polyunsaturated fatty acids (PUFA) have been shown to reduce the susceptibility of LDL to oxidative modification (Reaven et al., 1993). Diets rich in both oleic acid and linoleic acid are an important component of a cholesterol-lowering diet. Therefore, an emphasis on a balance of unsaturated fatty acids is important when selecting food sources to replace saturated fatty acids in the diet (Binkoski et al., 2005).

Phytosterols (ST) and phytostanols are lipid compounds structurally similar to cholesterol. The intake of phytosterols and/or phytostanols at the level of $1.5-3.0 \mathrm{~g} /$ day has been documented to reduce blood LDL-C by $10 \%$ (Katan et al., 2003; Demontyl et al., 2009). The efficacy and safety of phytosterol- and phytostanol-enriched food products have been reviewed by several regulatory agencies. Also, the sale of phytosterol and phytostanol-enriched food products has been approved as a means to reduce blood cholesterol levels by many European countries (European Food Safety Authority, 2008), the United States (U.S. Food and Drug Administration, 2000), Australia and New Zealand (Commonwealth of Australia, Australia New Zealand Food Standards, 2006). Vitamin $E$ is a central fat-soluble vitamin which is a vitamin of youth, beauty and continuation of the species. Deficiency of this compound affects many tissues in mammalian and bird models (Nelson, 1980). A vitamin E deficiency in humans causes defects in the developing nervous system of children and hemolysis in adults (Sokol, 1996). Eipdemiologic studies suggest that people with lower vitamin $\mathrm{E}$ levels and other antioxidants may be at increased risk for certain types of cancer and atherosclerosis (Gey et al., 1991; Rimm et al., 1993). It is also suggested that supplementation with antioxidants may decrease the risk of these and other degenerative processes (Kallio et al., 2002). High levels of vitamin E and PUFA in oil raise the food value of the oil. Tocopherols in vegetable oils, moreover, are believed to protect PUFA from peroxidation (Kamal-Eldin and Andersson, 1997). The presence of natural antioxidants such as vitamin $E$ is a factor determining the resistance of oils to autooxidation.

The processing of many fruits results in the accumulation of large quantities of by-products. Proper use of this by-product could reduce waste disposal problems and serve as a potential new source of fats and proteins for use in food and feed (Ramadan and Moersel, 2003). Most of the apricots are processed in the fruit juice industry or dried. The apricot kernel contains $40 \%$ oil which is composed of $30 \%$ linoleic acid (C18:2) and $60 \%$ oleic acid (C18:1) (Al-Khalifa, 1996). Apricot oil (AO) is also a good source of vitamin $E(78 \mathrm{mg} / 100 \mathrm{~g})$ and ST (Sizova and Andreeva, 2007). Pumpkin seeds are an excellent source of protein $36.5 \%$ and oil $51 \%$. Pumpkin kernel oil (PO) is a common salad oil and is composed of $55.6 \%$ linoleic and $20.4 \%$ oleic acid (El-Adawy and Taha, 2001). PO is especially high in the $\gamma$-tocopherol form of vitamin $\mathrm{E}$, which is a powerful antioxidant, so it protects important biological molecules from oxidative stress (Stevenson et al., 2007). The aims of the present study were to explore the fatty acid profiles, ST and tocopherols in apricot and pumpkin kernel coldpressed oils and to investigate the impact of both oils on the lipid profile and liver functions of rats fed a hypercholesterolemic diet.

\section{MATERIALS AND METHODS}

\subsection{Materials and oils}

Cold-pressed $\mathrm{AO}$ and $\mathrm{PO}$ were purchased from the local market (Zagazig, Egypt). Standards used for ST characterization were purchased from Supelco (Bellefonte, PA, USA). Standards used for vitamin $E(\alpha-, \beta-, \gamma-$ and $\delta$-tocopherol) were purchased from Merck (Darmstadt, Germany). Reagents and chemicals were of the highest purity available.

\subsection{Methods}

\subsubsection{Gas chromatography (GC) analysis of fatty acid methyl esters (FAME)}

Fatty acids were transesterified into FAME using N-trimethylsulfoniumhydroxide (MachereyNagel, Düren, Germany) according to the procedure reported by (Arens et al., 1994). FAME were identified on a Shimadzu GC-14A equipped with flame ionization detector (FID) and C-R4AX chromatopac integrator (Kyoto, Japan). The flow rate of the carrier gas helium was $0.6 \mathrm{~mL} / \mathrm{min}$ and the split value with a ratio of $1: 40$. A sample of $1 \mu \mathrm{L}$ was injected onto a $30 \mathrm{~m} \times 0.25 \mathrm{~mm} \times 0.2$ $\mu \mathrm{m}$ film Supelco SP ${ }^{\mathrm{TM}}$-2380 (Bellefonte, PA, USA) capillary column. The injector and FID temperature was set at $250^{\circ} \mathrm{C}$. The initial column temperature was $100^{\circ} \mathrm{C}$ programmed at $5^{\circ} \mathrm{C} / \mathrm{min}$ up to $175^{\circ} \mathrm{C}$ and held for $10 \mathrm{~min}$ at $175^{\circ} \mathrm{C}$, then $8^{\circ} \mathrm{C} / \mathrm{min}$ up to $220^{\circ} \mathrm{C}$ and held for $10 \mathrm{~min}$ at $220^{\circ} \mathrm{C}$. A comparison between the retention times of the samples with those of authentic standard mixture (Sigma, St. Louis, MO, USA; 99\% purity specific for GLC), run on the same column under the same conditions, was made to facilitate identification.

\subsubsection{Gas chromatography (GC) analysis of $S T$}

Separation of ST was performed after saponification of the oil sample without derivatization according 
to (Ramadan et al., 2007). Oil samples (250 mg) were refluxed with a $5 \mathrm{~mL}$ ethanolic potassium hydroxide solution $(6 \%, w / v)$ and a few anti-bumping granules for $60 \mathrm{~min}$. The unsaponifiables were first extracted 3-times with $10 \mathrm{~mL}$ petroleum ether. The extracts were combined and washed 3-times with $10 \mathrm{~mL}$ of neutral ethanol/water $(1: 1, \mathrm{v} / \mathrm{v})$ and then dried overnight with anhydrous sodium sulphate. The extract was evaporated in a rotary evaporator at $25^{\circ} \mathrm{C}$ under reduced pressure, and then ether was completely evaporated under nitrogen. GLC analyses of unsaponifiable residues were carried out using a Mega Series (HRGC 5160, Carlo Erba Strumentazione; Milan, Italy) equipped with FID. The following parameters were performed: DB 5 column (J\&W scientific; Falsom, CA, USA) packed with 5\% phenylmethylpolysiloxan, $30 \mathrm{~m}$ length, $0.25 \mathrm{~mm}$ i.d., $1.0 \mu \mathrm{m}$ film thickness; carrier gas (helium) flow $38 \mathrm{~mL} /$ min (split-splitless injection was used). Detector and injector were set at $280^{\circ} \mathrm{C}$. The oven temperature was kept constant at $310^{\circ} \mathrm{C}$ and the injected volume was $2 \mu \mathrm{L}$. The repeatability of the analytical procedure was tested and the relative standard deviation of three repeated analyses of a single sample was $<5 \%$. Quantitative analyses were performed with a Shimadzu (C-R6A Chromatopac; Kyoto, Japan) integrator.

\subsubsection{Normal phase high performance liquid chromatography (NP-HPLC) separation, identification and quantification of tocopherols}

Procedure: NP-HPLC was selected to avoid extra sample treatment (e.g., saponification) according to (Ramadan et al., 2010). The analysis was performed with a solvent delivery LC-9A HPLC (Shimadzu, Kyoto, Japan). The chromatographic system included a model 87.00 variable wavelength detector and a $250 \times 4 \mathrm{~mm}$ i.d. LiChrospher-Si 60, $5 \mu \mathrm{m}$, column (Knauer, Berlin, Germany). The separation of tocopherol isomers was based on isocratic elution when the solvent flow rate was maintained at $1 \mathrm{~mL} / \mathrm{min}$ at a column back-pressure of about 65-70 bar. The solvent system selected for elution was isooctane/ethyl acetate (96:4, v/v) with detection at $295 \mathrm{~nm}$. Twenty $\mu \mathrm{L}$ of the diluted solution of $\mathrm{TL}$ in the mobile phase were directly injected into the HPLC column. Tocopherol isomers were identified by comparing their retention times with those of authentic standards.

Preparation of standard curves: Standard solutions were prepared by serial dilution to a concentration of approximately $5 \mathrm{mg} \mathrm{mL} \mathrm{mg}^{-1}$ of each tocopherol isomer. Standard solutions were prepared from a stock solution which was stored in the dark at $-20^{\circ} \mathrm{C}$. Twenty $\mu \mathrm{L}$ were injected and peak areas were determined to generate standard curve data.

Quantification: All quantitation was by peak area using a Shimadzu C-R6A chromatopac integrator (Kyoto, Japan). Standard curves (concentration versus peak area) were calculated from six concentration levels by linear regression. Based on the established chromatographic conditions, repeated injections of different concentrations of the standard tocopherols were made 3-times onto the HPLC system. Injections in triplicate were made at each concentration for both standards and samples. All work was carried out under subdued light conditions. All the experiments were repeated at least three times when the variation of any one was routinely less than $5 \%$.

\subsubsection{Experimental diets}

The composition of the experimental diets is detailed in Table 1. Table 2 presents the composition of minerals and vitamins in the diet used in this study.

\subsubsection{Animal experiments}

The work was carried out at the Biochemistry Department, Faculty of Agriculture, Menofia University (Egypt). To study the effect of the AO and PO on lipid profiles and liver functions of albino rats, twenty-four male albino rats (weighting between 110 and $130 \mathrm{~g}$ ) were used for this investigation. The rats were obtained from The Research Institute of Ophthalmology (Giza, Egypt). The rats were fed ad libitum on a basal diet (BD) and water for 15 days as an adaptation period. They were housed individually in stainless steel cages and divided into four groups of six animals. The negative control group was fed only the BD, while the other groups were fed the hypercholesterolemic high fat diet. The second group went without any treatment (hypercholesterolemic group or positive control) and the other groups were fed by stomach tube $(1 \mathrm{~g} /$ $\mathrm{Kg}$ body weight as a daily basis) with apricot kernel oil (AO group), while the last group was treated with pumpkin kernel oil (PO group). Their food intake

Table 1

Chemical composition $(\mathrm{g} / \mathrm{kg})$ and calculated analysis of experimental diets

\begin{tabular}{lcc}
\hline & High fat diet & Standard diet \\
\hline Casein & 150 & 150 \\
Starch & 537.5 & 647.5 \\
Corn oil & 100 & 100 \\
Salt mixture & 40 & 40 \\
Vitamin mixture & 10 & 10 \\
Cellulose & 50 & 50 \\
Colic acid & 2.5 & 2.5 \\
Cholesterol & 10 & - \\
Sheep tail fat & 100 & - \\
\hline
\end{tabular}

Fatty acid composition of sheep tail fat including myristic (5\%), palmitic $(21.7 \%)$, stearic $(22 \%)$, palmitoleic $(1.5 \%)$, oleic $(43 \%)$, linoleic $(3.8 \%)$ and linolenic $(3 \%)$. The level of cholesterol in sheep tail fat is $100 \mathrm{mg} / 100 \mathrm{~g}$. 
Table 2

Composition of vitamins and mineral mixture in diets*

\begin{tabular}{lccc}
\hline \multicolumn{1}{c}{ Vitamin } & Quantity & Mineral & Quantity \\
\hline Vitamin A & $2000 \mathrm{iu}$ & $\mathrm{NaCl}$ & $0.50 \%$ \\
Vitamin D & $200 \mathrm{iu}$ & $\mathrm{KI}$ & $0.013 \%$ \\
Vitamin E & $75 \mathrm{iu}$ & $\mathrm{K}_{2} \mathrm{HPO}_{4}$ & $1.62 \%$ \\
Vitamin K & $0.5 \mathrm{mg}$ & $\mathrm{MgSO}_{4}$ & $0.325 \%$ \\
Inositol & $10 \mathrm{mg}$ & $\mathrm{CaCO}_{3}$ & $1.50 \%$ \\
Niacin & $4.0 \mathrm{mg}$ & $\mathrm{CaHPO}_{4}$ & $0.30 \%$ \\
Ca pantothenate & $4.0 \mathrm{mg}$ & $\mathrm{FeSO}_{4}$ & $0.125 \%$ \\
Riboflavin & $0.8 \mathrm{mg}$ & $\mathrm{CuSO}_{4}$ & $0.0015 \%$ \\
Thiamin HCL & $0.5 \mathrm{mg}$ & $\mathrm{MnSO}_{4}$ & $0.011 \%$ \\
Pyridoxine & $0.5 \mathrm{mg}$ & $\mathrm{ZnSO}_{4}$ & $0.00916 \%$ \\
Folic acid & $0.2 \mathrm{mg}$ & & \\
Biotin & $0.04 \mathrm{mg}$ & & \\
Vitamin B & & & \\
Choline chloride & $0.003 \mathrm{mg}$ & & \\
Para amino benzoic acid & $200 \mathrm{mg}$ & & \\
\hline
\end{tabular}

*starch was added to make $1000 \mathrm{mg}$.

was monitored daily and all the rats fasted before blood sampling. The blood samples were drawn from eye plexuses after 14 and 28 days. The rats were anesthetized using diethyl ether. The weight gain of the rats was recorded weekly.

\subsubsection{Blood sampling and analysis}

Blood samples were collected after 14 and 28 days in tubes containing heparin as an anticoagulant from the eye plexuses under diethyl ether anesthesia and then centrifuged at 3000 rpm for 20 min to obtain plasma, which was kept frozen until analysis. The total cholesterol was analyzed according to Richmond (1973). HDL-C was determined according to López et al. (1977). According to Demacker et al. (1984) LDL-C was calculated as the difference between total cholesterol and HDL-C. The triglycerides were analyzed according to Fossati and Prencipe (1982). Alanine-aminotransferase (ALT) and aspartateaminotransferase (AST) activities were measured according to the method described by Retiman and Frankel (1957). Total protein was determined according to Tietz, (1976). Albumin was determined according to Doumas et al. (1971).

\subsubsection{Statistical analysis}

The results of the animal experiments were expressed as the mean $\pm S D$ and they were analyzed statistically using the one-way analysis of variance ANOVA followed by Duncan's test.
In all cases $p<0.05$ was used as the criterion of statistical significance.

\section{RESULTS}

\subsection{Fatty acid profile of $A O$ and $P O$}

The Fatty acid composition of $\mathrm{AO}$ and $\mathrm{PO}$ is presented in Table 3. According to the results shown, eight fatty acids were identified in both oils, while

Table 3

Levels of fatty acid (\%) in apricot and pumpkin kernel oils

\begin{tabular}{lcc}
\hline \multicolumn{1}{c}{ Fatty acid } & AO & PO \\
\hline C14:0 & $\mathrm{nd}^{\mathrm{a}}$ & $0.20 \pm 0.04$ \\
C16:0 & $4.50 \pm 0.14$ & $13.5 \pm 0.23$ \\
C16:1n-7 & $0.61 \pm 0.02$ & $0.27 \pm 0.07$ \\
C18:0 & $1.24 \pm 0.34$ & $6.92 \pm 0.77$ \\
C18:1n-9 & $70.9 \pm 2.64$ & $35.3 \pm 1.34$ \\
C18:2n-6 & $22.5 \pm 1.00$ & $42.6 \pm 1.55$ \\
C20:0 & $0.12 \pm 0.03$ & $0.53 \pm 0.05$ \\
C18:3n-3 & $0.13 \pm 0.02$ & $0.68 \pm 0.04$ \\
U/S & 16.0 & 3.72 \\
\hline
\end{tabular}

${ }^{a}$ not detected.

${ }^{\mathrm{b}}$ Unsaturation ratio $=(16: 1+18: 1+18: 2+18: 3) /(14: 0+$ $16: 0+18: 0+20: 0)$.

Results are given as mean \pm SD from triplicate estimations. 
Table 4

Profile of phytosterols ( $\mathrm{mg} / \mathrm{kg}$ oil) in AO and PO

\begin{tabular}{lcc}
\hline \multicolumn{1}{c}{ Compound } & AO & PO \\
\hline$\alpha$-Spinasterol (D7,22-stigmastadien-3b-ol) & $\mathrm{nd}^{\mathrm{a}}$ & $398 \pm 3.04$ \\
Campesterol & $130 \pm 2.44$ & $20.0 \pm 0.55$ \\
Stigmasterol & $31.0 \pm 0.67$ & $27.0 \pm 0.38$ \\
$\beta$-Sitosterol & $755 \pm 2.66$ & $86.0 \pm 1.43$ \\
$\Delta$ 5-Avenasterol & $295 \pm 1.98$ & $\mathrm{nd}$ \\
$\Delta$ 5, 24 stigmastadienol & $25.0 \pm 0.99$ & $\mathrm{nd}$ \\
$\Delta$ 7-stigmastenol & $32.0 \pm 0.89$ & $\mathrm{nd}$ \\
$\Delta$ 7-Avenasterol & $\mathrm{nd}$ & $230 \pm 2.22$ \\
Other sterols/stanols & $50.0 \pm 0.66$ & $580 \pm 3.04$ \\
Total ST content & 1318 & 943 \\
\hline
\end{tabular}

a not detected.

Results are given as mean \pm SD from triplicate estimations.

the analysis of FAME gave the proportion of oleic, linoleic, palmitic and stearic as the major fatty acids, which comprised together more than $90 \%$ of the total identified FAME in $\mathrm{AO}$ and PO. In AO the major fatty acid was oleic acid $(70.9 \%)$ while in PO the major fatty acid was linoleic (42.6\%). Concerning saturated fatty acids (especially palmetic and stearic), $\mathrm{AO}$ and $\mathrm{PO}$ were characterized by appreciable levels of saturates. A striking feature of $A O$ and $P O$ was the relatively high level of PUFA, especially linoleic, acid in PO.

\subsection{Phytosterol composition of $A O$ and $P O$}

Eight ST compounds were postulated and the ST marker in AO was $\beta$-sitosterol which comprised 755 $\mathrm{mg} / \mathrm{kg}$ oil (Table 4). The next major components was $\Delta 5$-Avenasterol (295 mg/kg oil), while campesterol, stigmasterol, $\Delta 7$-stigmastenol, $\Delta 5,24$ stigmastadienol were present at lower levels. $\alpha$-Spinasterol $(\Delta 7$, 22-stigmastadien-3b-ol) and $\Delta 7$-avenasterol were not detected. In PO the ST marker was $\alpha$-spinasterol which comprised $398 \mathrm{mg} / \mathrm{kg}$ oil, and also $\Delta 7$-avenasterol (230 mg/kg oil) was detected, while $\beta$-sitosterol, stigmasterol, and campesterol were found in lower levels. $\Delta 5$-Avenasterol, $\Delta 5,24$ stigmastadienol, $\Delta 7-$ stigmastenol were not detected.

\subsection{Tocopherol composition of $\mathrm{AO}$ and $\mathrm{PO}$}

Tocopherols are the major lipid-soluble, membrane-localized antioxidants in humans. The data relating to the qualitative and quantitative compositions of vitamin $\mathrm{E}$ in $\mathrm{AO}$ and $\mathrm{PO}$ are summarized in Table 5. The saponification of the oil samples was not required, which allowed shorter analysis time and greater vitamin stability during analysis (Ramadan and Moersel, 2002). Different patterns of tocopherols were detected in the oil samples under study. $\alpha, \gamma$ and $\delta$ - tocopherols were the major isomers in both oils. AO contained a large amount $(520 \mathrm{mg} / \mathrm{kg}$ oil) of $\gamma$-tocopherol, while a low level of $\beta$-tocopherol $(0.33 \mathrm{mg} / \mathrm{kg}$ oil) was measured. In PO $\delta$-tocopherol was the major isomer, followed by $\gamma$-tocopherol, together comprising $902 \mathrm{mg} / \mathrm{kg}$ oil, while $\beta$-tocopherol was not detected.

\subsection{Impact of $A O$ and $P O$ supplementation on the plasma lipid profile}

The data in Table 6 show the concentrations of different plasma lipids in all the groups. After 14 days, the results revealed that $\mathrm{PO}$ and $\mathrm{AO}$ groups showed decreases in plasma triglycerides, total cholesterol and LDL-C in comparison with the control group. HDL-C showed another response, the hypercholesterolemic group had the lowest concentration followed by $\mathrm{AO}$ and then $\mathrm{PO}$ groups. No significant differences in body weight were recoded among groups (data not schown). Data in Table (7) show the impact of feeding AO and PO on plasma lipid profiles after 28 days. Results show that feeding $\mathrm{PO}$ and $\mathrm{AO}$ produced substantial decreases in the concentrations of triglycerides, total cholesterol and LDL -C.

Table 5

Profile of tocopherols ( $\mathrm{mg} / \mathrm{kg}$ oil) in AO and PO

\begin{tabular}{lcc}
\hline \multicolumn{1}{c}{ Compound } & AO & PO \\
\hline$\alpha$-Tocopherol & $22.0 \pm 0.23$ & $77.0 \pm 0.99$ \\
$\beta$-Tocopherol & $0.33 \pm 0.06$ & $\mathrm{nd}^{\mathrm{a}}$ \\
$\gamma$-Tocopherol & $520 \pm 3.22$ & $355 \pm 2.06$ \\
$\delta$-Tocopherol & $17.5 \pm 0.33$ & $547 \pm 2.54$ \\
Total tocopherols & 559.8 & 979 \\
\hline
\end{tabular}

a not detected.

Results are given as mean $\pm \mathrm{SD}$ from triplicate estimations. 
Table 6

Plasma lipid profile in rats fed high-fat diets supplemented with PO or AO after 14 days

\begin{tabular}{ccccc}
\hline Groups & $\begin{array}{c}\text { Triglycerides } \\
\mathbf{m g} / \mathbf{d l}\end{array}$ & $\begin{array}{c}\text { Total cholesterol } \\
\mathbf{m g} / \mathbf{d l}\end{array}$ & $\begin{array}{c}\text { HDL-C } \\
\mathbf{m g} / \mathbf{d l}\end{array}$ & $\begin{array}{c}\text { LDL-C } \\
\mathbf{m g} / \mathbf{d l}\end{array}$ \\
\hline $\begin{array}{c}\text { Control (negative) } \\
\text { Hypercholesterolemic } \\
\text { control }\end{array}$ & $142.0 \pm 4.83 \mathrm{~d}$ & $82.5 \pm 2.64 \mathrm{c}$ & $68.0 \pm 3.56 \mathrm{a}$ & $14.5 \pm 1.0 \mathrm{~d}$ \\
PO & $344.0 \pm 6.32 \mathrm{a}$ & $139 \pm 4.55 \mathrm{a}$ & $31.7 \pm 3.09 \mathrm{c}$ & $107.2 \pm 2.06 \mathrm{a}$ \\
AO & $216.5 \pm 6.8 \mathrm{c}$ & $115 \pm 3.91 \mathrm{~b}$ & $42.2 \pm 4.03 \mathrm{~b}$ & $72.2 \pm 7.5 \mathrm{c}$ \\
LSD 0.05 & $244.5 \pm 5.0 \mathrm{~b}$ & $118.5 \pm 5.45 \mathrm{~b}$ & $33.0 \pm 3.66 \mathrm{c}$ & $85.5 \pm 5.0 \mathrm{~b}$ \\
\hline
\end{tabular}

$(a, b, c, d)$ means in the same column followed by the same letters do not differ significantly, and when the values followed by different letters differ significantly at $p \leq 0.05$. Each value represents a mean of 6 samples \pm standard deviation (SD).

Table 7

Plasma lipid profile in rats fed high-fat diets supplemented with PO or AO after 28 days

\begin{tabular}{ccccc}
\hline Groups & $\begin{array}{c}\text { Triglycerides } \\
\mathbf{m g} / \mathbf{d l}\end{array}$ & $\begin{array}{c}\text { Total cholesterol } \\
\mathbf{m g} / \mathbf{d l}\end{array}$ & $\begin{array}{c}\text { HDL-C } \\
\mathbf{m g} / \mathbf{d l}\end{array}$ & $\begin{array}{c}\text { LDL-C } \\
\mathbf{m g} / \mathbf{d l}\end{array}$ \\
\hline $\begin{array}{c}\text { Control (negative) } \\
\text { Hypercholesterolemic } \\
\text { control }\end{array}$ & $134.7 \pm 6.2 \mathrm{~d}$ & $92.5 \pm 4.8 \mathrm{~d}$ & $75.5 \pm 5.8 \mathrm{a}$ & $17 \pm 2.71 \mathrm{~d}$ \\
PO & $357.0 \pm 7.8 \mathrm{a}$ & $192.7 \pm 4.5 \mathrm{a}$ & $40.7 \pm 1.7 \mathrm{a}$ & $112.0 \pm 5.9 \mathrm{a}$ \\
AO & $161.2 \pm 2.6 \mathrm{c}$ & $106.2 \pm 3.7 \mathrm{c}$ & $67.0 \pm 3.7 \mathrm{~b}$ & $39.2 \pm 1.26 \mathrm{c}$ \\
LSD & $205.5 \pm 6.1 \mathrm{~b}$ & $119.7 \pm 3.1 \mathrm{~b}$ & $44.7 \pm 3.1 \mathrm{c}$ & $75 \pm 0.12 \mathrm{~b}$ \\
\hline
\end{tabular}

$(a, b, c, d)$ means in the same column followed by the same letters do not differ significantly, and when the values followed by different letters differ significantly at $p \leq 0.05$. Each value represents a mean of 6 samples \pm standard deviation (SD).

\subsection{Impact of $A O$ and $P O$ supplementation on liver functions}

The effect of feeding $\mathrm{AO}$ and $\mathrm{PO}$ is presented in Figure 1, which explains the variation between the control and the other treated groups. It can be noticed that the levels of ALT and AST enzyme activity in the hypercholesterolemic control was higher compared with the other groups. The reducing effect of feeding $\mathrm{PO}$ and $\mathrm{AO}$ compared with the hypercholesterolemic control can also be seen after 14 days of feeding. On the other hand, the hypercholesterolemic control group $(\mathrm{C}+)$ had lower levels of total protein and albumin compared with the negative control (C-). Both the $\mathrm{PO}$ and $\mathrm{AO}$ groups showed higher levels of total protein and albumin levels compared with the hypercholesterolemic group. Figure 2 demonstrates what happened when the experimental period became 28 days. It can be noticed that all groups showed the same effect after 14 days.

\section{DISCUSSION}

\subsection{Fatty acid profile and bioactive lipids of $\mathrm{AO}$ and $\mathrm{PO}$}

The analysis of FAME in AO and PO (Table 3) gave the proportions of oleic, linoleic, palmitic and stearic as the major fatty acids, together comprising more than $90 \%$ of the total identified FAME. In AO the major fatty acid was oleic acid $(70.9 \%)$ followed by linoleic acid (22.5\%) and these data are in line with Al-Khalifa (1996). In PO the major fatty acid was linoleic (42.6\%) followed by oleic acid (35.3\%) which is very close to the results of El-Adawy and Taha (2001). The benefits of oleic and linoleic

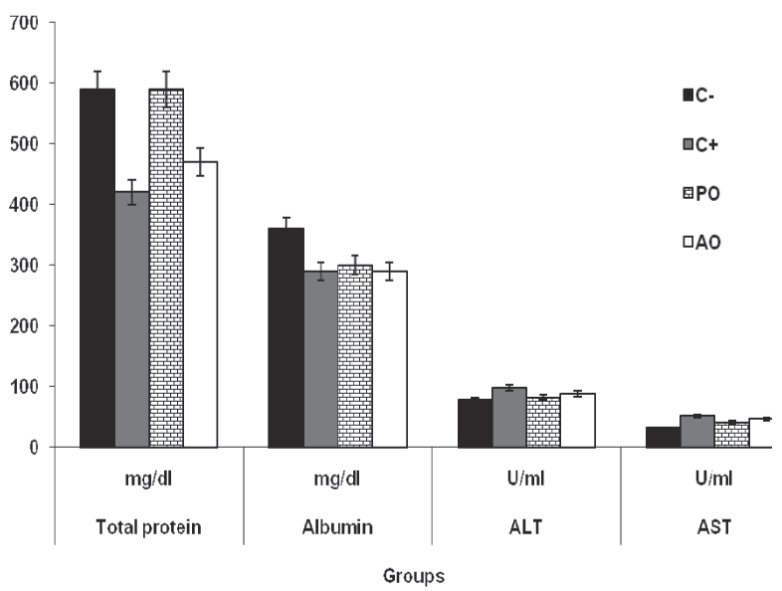

Figure 1

Impact of $\mathrm{AO}$ and $\mathrm{PO}$ supplementation on liver functions after 14 days. Values given are the mean of three replicates and error bars show the variations of three determinations in terms of standard deviation. 


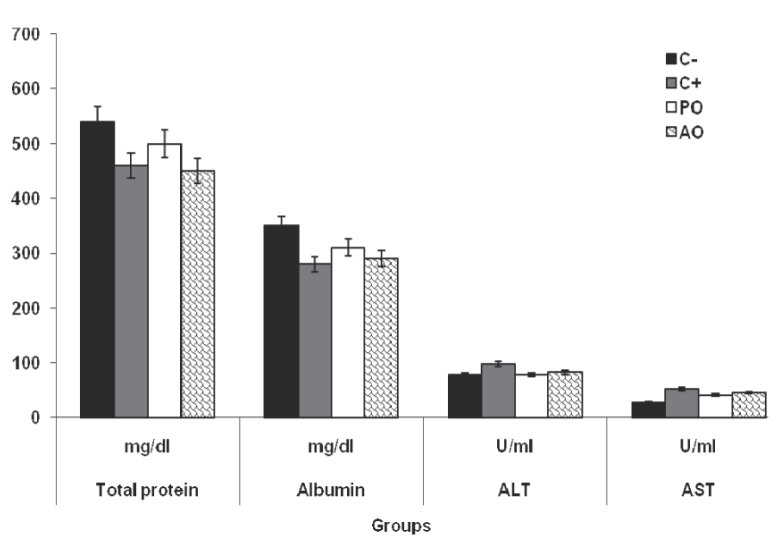

Figure 2

Impact of $\mathrm{AO}$ and $\mathrm{PO}$ supplementation on liver functions after 28 days. Values given are the mean of three replicates and error bars show the variations of three determinations in terms of standard deviation.

acids in reducing cholesterol levels were reported by Binkoski et al., (2005) who explained the role of an unsaturated fatty acid balance when selecting food sources to replace saturated fatty acids in the diet. Thus, it can be concluded that high levels of oleic and linoleic acids in $\mathrm{AO}$ and $\mathrm{PO}$ may give high nutritional values for $\mathrm{AO}$ and $\mathrm{PO}$.

Vegetable oils are generally regarded as important sources for ST since in general they contain relatively higher ST than vegetables and fruits (Piironen et al., 2000; Alvarez-Chavez et al., 2008). Associations between ST intake and cancer or $\mathrm{CHD}$ risk to date were difficult to assess because of the lack of data covering ST levels in foods. New databases (Schwartz et al., 2008) have been recently published. Levels of ST in vegetable oils are used for the identification of oils and oil derivatives and for the determination of oil quality (Grob et al., 1990; Artho et al., 1993; De-Blas and Del-Valle, 1996). Our data in Table 4 showed a high total ST level in AO (1318 mg/kg oil) and in PO (943 mg/kg oil). Phytosterols, in general, are of interest due to their antioxidant activity and impact on health and many beneficial effects have been shown for the sitosterol (Yang et al., 2001). Recently, ST have been added to vegetable oils as an example of a biologically based functional food (Ntanios, 2001). Katan et al. (2003) and Demontyl et al. (2009) demonstrated the vital role of ST in LDL-C reduction. The results stated that $\mathrm{AO}$ and $\mathrm{PO}$ are rich in ST which may have different functions in human bodies especially as antioxidant agents.

The data in Table 5 show PO to have a large amount of total tocopherols ( $979 \mathrm{mg} / \mathrm{kg}$ oil), while AO has (559.8 mg/kg oil). This means that both PO and $A O$ are good sources of tocopherols which may provide high protective antioxidant effects for those cold-pressed oils. Kamal-Eldin and Andersson (1997) investigated the important role of different tocopherols in protecting PUFA from peroxidation. Punithavathi and Prince (2009) determined that a combined treatment of quercetin $(10 \mathrm{mg} / \mathrm{kg})$ with $\alpha$-tocopherol (10mg/ $\mathrm{kg}$ ) resulted in reducing cholesterol and triglycerides levels. Evidence indicates that dietary antioxidants may modulate the endothelium-dependent vascular functions through several mechanisms and may contribute to the prevention of vascular diseases such as atherosclerosis. Cell cultures as well as animal and human clinical and observational studies have tested the efficacy of vitamin $E$ on vascular function and the prevention of atherosclerosis. Vitamin $\mathrm{E}$ ( $\alpha$-tocopherol) inhibited the activation of endothelial cells stimulated by high levels of LDL-cholesterol and pro-inflammatory cytokines. This inhibition is associated with the suppression of chemokines, the expression of cell surface adhesion molecules, and the adhesion of leukocytes to endothelial cells, all of which contribute to the development of lesions in the arterial wall. Moreover, the positive effect of dietary vitamin $E$ on endothelium and vascular functions in animal models of atherosclerosis was demonstrated (Meydani, 2004).

\subsection{Impact of AO and OP supplementation on the plasma lipid profile}

Hyperlipidemia mainly increased the levels of cholesterol or LDL-C which is an important risk factor in the initiation and progression of atherosclerotic lesions (Harrison et al., 2003). In our study (Tables 6 and 7 ), it can be noted that the hypercholesterolemic control group fed the high fat diet showed high levels of triglycerides (344 mg/dl after 14 days and $357 \mathrm{mg} / \mathrm{dl}$ after 28 days), total cholesterol $(139 \mathrm{mg} / \mathrm{dl}$ after 14 days and 192.75 $\mathrm{mg} / \mathrm{dl}$ after 28 days), and LDL-C which were greatly increased (107.25 mg/dl after 14 days and $112 \mathrm{mg} /$ dl after 28 days) compared with the control group. On the other hand, $\mathrm{PO}$ and $\mathrm{AO}$ groups showed lower levels of lipid profile parameters which are in line with Kurushimaa et al. (1995) who reported that feeding linoleic and oleic acid (5\%) decreased levels of triglycerides, total cholesterol and LDL-C. Also, from Tables 6 and 7 we can notice that the $\mathrm{PO}$ group has a more positive effect than the $\mathrm{AO}$ group. PO has a high content of linoleic acid $(42.6 \%)$ while $\mathrm{AO}$ has a good amount of linoleic acid $(22.5 \%)$. The cholesterol-lowering effect of linoleic acid is well established from human trials. In a meta-analysis of 60 feeding studies including 1672 volunteers, the substitution of PUFA (largely omega- 6 , varying from $0.6 \%$ to $28.8 \%$ energy) for carbohydrates had more favorable effects on the ratio of total to HDL-C than any class of fatty acids (Mensink et al., 2003). Epidemiologically, the replacement of $10 \%$ of calories from saturated fatty acids with omega-6 PUFA is associated with an 18 $\mathrm{mg} / \mathrm{dl}$ decrease in LDL-C which was even greater than that observed with similar replacement with carbohydrates (Mensink and Katan, 1992).

AO has high content of oleic acid $(70.9 \%)$ while PO has a good amount of oleic acid (35.3\%). Oleic acid (monounsaturated fatty acid) was reported to reduce total plasma cholesterol and LDL-C (Grundy, 
1986). Moreover, an epidemiological study showed that death rates from coronary heart disease were relatively low in countries such as Greece and southern Italy, where the traditional diet was high in olive oil which is rich in oleic acid (Keys et al., 1986).

There are several explanations about the mechanisms by which dietary fatty acids affect plasma cholesterol concentrations such as changes in lipoprotein composition (Shore et al., 1981), in LDL production (Turner et al., 1981), and in very low density cholesterol (VLDL) secretion from the liver and hepatic LDL receptor activity (Othani et al., 1990; Hayashi et al., 1993). Moreover, PUFA as compared to saturated fatty acids are less efficiently incorporated into triglycerides synthesized by the liver for the export of VLDL (Cortese et al., 1983). Jump and Clarke (1999), investigated diets rich in long chain PUFA which stimulate both gene expression and the activation of enzymes involved in $\beta$-oxidation. Also, the data in Tables (6 and 7) showed that the PO group has the better reduction in total plasma cholesterol and LDL-C than the AO group, whcih may be due to the high linoleic acid content in $\mathrm{PO}$ compared with $\mathrm{AO}$ which has a high content of oleic acid. Kurushimaa et al. (1995) suggested that the suppression of hepatic LDL receptor activity was prevented by either linoleic acid or oleic acid, although linoleic acid was more effective in preventing LDL receptor suppression than oleic acid. It must be mentioned also that hypercholesterolemic diets contained corn oil which is rich in linoleic or oleic fatty acids. Therefore, the hypocholesterolemic effect might depend on other bioactive compounents in oils such as ST and tocopherols.

Both $\mathrm{AO}$ and $\mathrm{PO}$ are rich in ST, which is widely reported to reduce serum cholesterol levels in animals and humans (Laraki et al., 1991; Howard and Kritchevsky, 1997). The hypocholesterolemic effect of ST may be explained by two mechanisms including the inhibition of (a) cholesterol absorption and (b) hepatic cholesterol esterase. On the other hand, ST have been shown to lower LDL cholesterol equivalently in hypercholesterolemic persons by suppressing cholesterol absorption (Vanstone et al., 2002). Plant sterols decreased the incorporation of dietary and biliary cholesterol into micelles and this lowers cholesterol absorption and ultimately leads to decreased serum LDL-C concentrations (De Jong et al., 2003; Ostlund et al., 2003).

Vitamin $E$ is a lipid soluble antioxidant that protects PUFA and other components of the cell and organelle membranes from the oxidation of reactive free radicals. Our data in Table 5 describe the tocopherol profiles of $\mathrm{AO}$ and $\mathrm{PO}$ and show the high content of total tocopherols in PO (979 mg/kg oil) and AO (559.83 $\mathrm{mg} / \mathrm{kg}$ oil). Vitamin E strongly affects cholesterol metabolism in the intestine (Landriera et al., 2010). In animal and human studies, supplementation with mixed tocotrienols has resulted in significant reductions in total serum cholesterol and LDL-C in hyperlipidemic pigs (Qureshi et al., 1991a) and hypercholesterolemic humans (Qureshi et al., 1991b; and Tan et al., 1991) and chickens (Qureshi et al., 1996). There is in vitro evidence that tocotrienols, members of the vitamin $\mathrm{E}$ family, are potent inhibitors of HMG-CoA reductase and decrease the synthesis of apolipoprotein B (Pearce et al., 1992; Theriault et al., 1999).

\subsection{Impact of $A O$ and $P O$ supplementation on liver functions}

In Figures 1 and 2 the hypercholesterolemic control group showed decreases in total protein and albumin compared with the control group. A low serum albumin indicates poor liver function. These results agree with Ghasi et al. (2000) who reported that the high-fat diet reduced serum albumin. In addition, the hypercholesterolemic group showed elevated ALT and AST activities in plasma. Oboh and Olumese (2010) recorded significant increases in the serum AST and ALT activities in rabbits fed a high fat diet (35\% palm oil) compared with the control group, fed a standard diet. Increases in serum activities of these enzymes are usually indicative of possible liver damage. $\mathrm{AO}$ and $\mathrm{PO}$ oils have high contents of oleic and linoleic acids, in addition to their high amounts of ST and tocopherols. Therefore, both $A O$ and $P O$ groups showed enhanced levels of ALT and AST in plasma, which may be due to the improving effect of these oils in lipid metabolism.

\section{CONCLUSIONS}

$\mathrm{AO}$ and $\mathrm{PO}$ afforded substantial protection to diet induced hyperlipidemic disorders and these effects are mainly mediated by minor components (ST and tocopherols) as well as by linoleic and oleic acids and their ratios. Further research, including food nutrition studies are needed to elucidate the human ability to eat $\mathrm{AO}$ and $\mathrm{PO}$ and the best ratio to add these oils to other common vegetable oils.

\section{REFERENCES}

Al-Khalifa AS. 1996. Physicochemical characteristics, fatty acids composition and lipoxygenase activity of crude pumpkin and melon seed oils. J. Agric. Food Chem. 44, $964-966$.

Alvarez-Chavez LM, Valdivia-Lopez M L, Aburto-Juarez ML, Tecantea A. 2008. Chemical characterization of the lipid fraction of Mexican Chia seed (Salvia hispanica L.). Inter. J. Food Prop. 11, 687-697.

Arens M, Schulte E, Weber K. 1994. Fettsäuremethylester, Umesterung mit Trimethylsulfoniumhydroxid (Schnellverfahren). Fat Sci. Technol. 96, 67-68.

Artho G, Grob K, Marianai C. 1993. On-line LC-GC for the analysis of the minor components in edible oils and fats- the direct method involving silylation. Fat Sci. Technol. 95, 176-180.

Binkoski AE, Kris-Etherton PM, Wilson TA, Mountain M L, Nicolosi RJ. 2005. Balance of unsaturated fatty acids is important to a cholesterol-lowering diet: Comparison of mid-oleic sunflower oil and olive oil on cardiovascular disease risk factors. J. Amer. Diet Assoc. 105, 1080-1086. 
Commonwealth of Australia: Australia New Zealand Food Standards Code Amendment No. 89 2006. http://www. foodstandards.gov.au

Cortese C, Levy Y, Janus ED. 1983. Modes of action of lipid lowering diets in mans: studies of apolipoprotein $B$ kinetics in relation to fat consumption and dietary fatty acids composition. Eur. J. Clin. Invest.13, 79-85.

Da Luz PL, Favarato D, Faria-Neto JR, Lemos $P$, Chagas AC. 2008. High ratio of triglycerides to HDLcholesterol predicts extensive coronary disease. Clinics (Sao Paulo) 63, 427-432.

Danielle AK, Brouns F, Hornstra G, Mensink RP. 2002. Effects on the human serum lipoprotein profile of $\beta$-glucan, soy protein and isoflavones, plant sterols and stanols, garlic and tocotrienols. J. Nutr.132, 2494-2505.

De Jong A, Plat J, Mensink RP. 2003. Metabolic effect of plant sterols and stanols. J. Nut. Biochem. 14, 362-369.

De-Blas OJ, Del-Valle GA. 1996. Determination of sterols by capillary column gas chromatography. Differentiation among different types of olive oil: virgin, refined and solvent extracted. J. Amer. Oil Chem. Soc. 73, 16851689.

Demacker AG, Hijmans BG, Brenninkmeijer AP, Jansen J S, van't Laar A. 1984. Five methods for determining low-density lipoprotein cholesterol compared. Clinic Chem. 30,1797-1800.

Demontyl I, Ras RT, Knaap van der HC, Duchateau GS Meijer L, Zock PL, Geleijnse JM, and Trautwein EA. 2009. Continuous dose-response relationship of the LDL cholesterol-lowering effect of phytosterol intake. J. Nutr. 139, 271-284.

Doumas BT, Watson WA, Biggs HG. 1971. Albumin standards and measurement of serum albumin with bromcresol green. Clin. Chim. Acta 31, 87-96.

Eisenberg S. 1984. High density lipoprotein metabolism. J. Lipid Res. 25,1017-1023.

El-Adawy TA, Taha KM. 2001. Characteristics and composition of different seed oils and flours. Food Chem. 74, 47-54.

European Food Safety Authority. 2008. Consumption of food and beverages with added plant sterols in the European Union. The Efsa Journal 133, 1-21.

Fossati P, Prencipe L. 1982. Serum triglycerides determined colorimetrically with an enzyme that produces hydrogen peroxide. Clinic Chem. 28, 2077-2080.

Gey KF, Puska P, Jordan P, Moser UK. 1991. Inverse correlation between plasma vitamin $\mathrm{E}$ and mortality from ischemic heart disease in cross-cultural epidemiology. Am. J. Clinic Nutr. 53, 3245-3265.

Ghasi S, Nwobodo E, Ofili JO. 2000. Hypocholesterolemic effects of crude extract of leaf of Moringa oleifera Lam in high-fat diet fed wistar rats. J. Ethnopharmacology 69, 21-25.

Grob K, Laufranchi M, Mariani C. 1990. Evaluation of olive oils through the fatty alcohols, the sterols and their esters by coupled LC-GC. J. Am. Oil Chem. Soc. 67, 626-634.

Grundy SM. 1986. Comparison of monounsaturated fatty acids and carbohydrates for lowering plasma cholesterol. New Eng. J. Med. 314, 745-749

Grundy SM. 1989. Monounsaturated fatty acids, plasma cholesterol and coronary heart disease. Am. J. Clin. Nutr. 45,1168-75.

Harrison D, Kathy KG, Hornig B, Drexler H. 2003. Role of oxidative stress in atherosclerosis. Amer. J. Card. 91, 7A-11A

Hayashi K, Hirata Y, Kurushima H, Saeki M. 1993. Effect of dietary hydrogenated corn oil (trans-octadecenoate rich oil) on plasma and hepatic cholesterol metabolism in the hamster. Atherosclerosis 99, 97-101.

Hermier D, Dillon J. 1992. Characterization of dietary induced hypercholesterolemia in the chicken. Biochem Brophys Acta 1124, 178-184.

Howard BV, Kritchevsky D. 1997. Phytochemical and cardiovascular disease. A statement for healthcare professionals from the American Heart Association. Circulation 95, 2591-2593.

Jump JO, Clarke SD. 1999. Regulation of gene expression by dietary fat. Ann. Rev. Nutr. 19, 63-90.

Kallio H, Yang B, Peippo P, Tahvonen R, Pan R. 2002. Triacylglycerols, glycerophospholipids, tocopherols and tocotrienols in berries and seeds of two subspecies (ssp. sinensis and mongolica) of Sea buckthorn (Hippophaë rhamnoides). J. Agric. Food Chem. 50, 3004-3009.

Kamal-Eldin A, Andersson R. 1997. A multivariate study of the correlation between tocopherol content and fatty acid composition in vegetable oils. J. Amer. Oil Chem. Soc. 74, 375-380.

Katan M B, Grundy SM, Jones P, Law M, Miettinen T, Paoletti RS. 2003. Workshop Participants: Efficacy and safety of plant stanols and sterols in the management of blood cholesterol levels. Mayo Clinic Proc. 78, 965-978.

Keys A, Menotti A, Karvonen MJ, Aravanis C, Blackburn H. 1986. The diet and 15-year death rate in the Seven Countries Study. Amer. J. Epidemiol. 124, 903-907.

Kurushimaa H, Hayashi K, Toyota Y, Kambeb M, Kajiyama G. 1995. Comparison of hypocholesterolemic effects induced by dietary linoleic acid and oleic acid in hamsters. Atherosclerosis 114, 213-221.

Landriera J, Gourantona E, Reboula E, Cardinaulta N, El Yazidia C. 2010. Vitamin E decreases endogenous cholesterol synthesis and apo-Al-mediated cholesterol secretion in Caco-2 cells. J. Nutr. Biochem. 21, 12071213

Laraki L, Pelletier X, Debry G. 1991. Effect of dietary cholesterol and phytosterol overload on wistar rat plasma lipids. Ann. Nut. Met. 35, 221-225.

Law MR. 1999. Lowering heart disease risk with cholesterol reduction: evidence from observational studies and clinical trials. Eur. Heart J. Suppl. 1, S3-S8.

Lopez MF, Stone S, Ellis S, Collwell JA. 1977. Cholesterol determination in high density lipoproteins separated by three different methods. Clin. Chem. 23, 882-886.

Mensink RP, Katan MB. 1992. Effect of dietary fatty acids on serum lipids and lipoproteins: a meta-analysis of 27 trials. Arterioscler. Thromb. 12, 911-919.

Mensink RP, Zock PL, Kester AD, Katan MB. 2003. Effects of dietary fatty acids and carbohydrates on the ratio of serum total to HDL cholesterol and on serum lipids and apolipoproteins: a meta-analysis of 60 controlled trials. Amer. J. Clinic Nutr. 77, 1146-1155.

Meydani M. 2004. Vitamin E modulation of cardiovascular disease. Ann. NY Acad. Sci 1031, 271-279.

Muldoon MF, Manuck SB, Mendelsohn AB, Kaplan JR, Belle SH. 2001. Cholesterol reduction and non-illness mortality: meta-analysis of randomized clinical trials. BMJ 322, 11-15.

Nelson JS. 1980. Pathology of vitamin E deficiency. In Vitamin E: A comprehensive treatise, Machlin LJ (ed), Marcel Dekker, NY; 397-428.

Ntanios F. 2001. Plant sterol-ester-enriched spreads as an example of a new functional food. Eur. J. Lipid Sci. Technol. 103, 102-106.

Oboh HA, Olumese FE. 2010. Effects of Low Carbohydrate High Fat Nigerian-Like Diet on Biochemical Indices in Rabbits. Pakistan J. Nutr. 3, 245-249. 
Ostlund RE, Racette SB, Stenson WF. 2003. Inhibition of cholesterol absorption by phytosterol-replete wheat germ compared with phytosterol-depleted wheat germ. Amer. J. Clin. Nutr. 77, 1385-1589.

Othani H, Hayashi K, Hirata Y, Dojo S. 1990. Effects of dietary cholesterol and fatty acids on plasma cholesterol level and hepatic lipoprotein metabolism. J. Lipid Res. 31, 1413-1418.

Pearce BC, Parker RA, Deason ME, Qureshi AA, Wright JJ. 1992. Hypocholesterolemic activity of synthetic and natural tocotrienols. J. Med. Chem. 35, 35953606 .

Piironen V, Toivo J, Lampi A.-M. 2000. Natural sources of dietary plant sterols. J. Food Comp. Anal. 13, 619-624.

Poli A, Marangoni F, Paoletti R, Mannarino E. 2008. Nonpharmacological control of plasma cholesterol levels. Nutrition, Metabolism and Cardiovascular Diseases 18, S1-S16.

Punithavathi VR, Prince SM. 2009. Combined effects of quercetin and $\alpha$-tocopherol on lipids and glycoprotein components in isoproterenol induced myocardial in fracted Wistar rats. Chemico-Biological Interactions 181, 322-327.

Qureshi AA, Pearce BC, Nor RM, Gapor A, Peterson DM, Elson CE. 1996. Dietary a-tocopherol attenuates the impact of g-tocotrienol on hepatic 3-hydroxy3-methylglutaryl coenzyme A reductase activity in chickens. J. Nutr. 126, 389-394.

Qureshi AA, Qureshi N, Hasler-Rapacz JO, Weber FE. 1991a. Dietary tocotrienols reduce concentrations of plasma cholesterol, apolipoprotein B, thromboxane B2, and platelet factor 4 in pigs with inherited hyperlipidemias. Amer. J. Clin. Nutr. 53,1042S-1046S.

Qureshi AA, Qureshi N, Wright JJ, Shen Z. 1991b. Lowering of serum cholesterol in hypercholesterolemic humans by tocotrienols (palmvitee). Amer. J. Clin. Nutr. 53,1021S-1026S.

Ramadan MF, Kinni SG, Seshagiri M, Mörsel J-T. 2010. Fat-soluble bioactives, fatty acid profile and radical scavenging activity of Semecarpus anacardium seed oil. J. Amer. Oil Chem. Soc. 87, 885-894.

Ramadan MF, Moersel J-T., 2002. Direct isocratic normal phase assay of fat-soluble vitamins and $\beta$-carotene in oilseeds. Eur. Food Res. Technol. 214, 521-527.

Ramadan MF, Mörsel J-T. 2003. Recovered lipids from prickly pear [(Opuntia ficus-indica (L.) Mill)] peel: a good source of polyunsaturated fatty acids, natural antioxidant vitamins and sterols. Food Chem. 83, 447-456.

Ramadan MF, Zayed R, El-Shamy H. 2007. Screening of bioactive lipids and radical scavenging potential of some solanaceae plants. Food Chem. 103, 885-890.

Reaven P, Parthasarathy S, Grasse BJ, Miller E, Steinberg D, Witztum JL. 1993. Effects of oleate-rich and linoleaterich diets on the susceptibility of low-density lipoprotein to oxidative modification in mildly hypercholesterolemic subjects. J. Clinic Invest. 91, 668-676.
Retiman S, Frankel S. 1957. Colorimetric determination of GOT and GPT. Am. J. Clinic Path. 28, 56-59.

Richmond W. 1973. Preparation and properties of a cholesterol oxidase from Nocardia sp. and its application to the enzymatic assay of total cholesterol in serum. Clinic Chem. 19, 1350-1356.

Rimm EB, Stampfer MJ, Ascherio A, Giovannucci E, Colditz GA, Willett WC. 1993. Vitamin E consumption and the risk of coronary heart disease in men. New Engl. J. Med. 328, 1450-1456.

Schwartz H, Ollilainen V, Piironen V, Lampi A-M. 2008. Tocopherol, tocotrienol and plant sterol contents of vegetable oils and industrial fats. J. Food Comp. Anal. 21, 152-161.

Shore VG, Krauss RM, Butterfield G, Dashaies Y, Lindgern FT. 1981. Effects of dietary polyunsaturated: saturated fat ratio on human serum lipoproteins. Arteriosclerosis $1,386 a$

Sizova NV, Andreeva NY. 2007. Estimation of vitamin E in plant oils by microcalorimetry. Pharm. Chem. J. 41, 337-340.

Sokol RJ. 1996. Vitamin E. In Present knowledge in Nutrition, Ziegler EE, Filer LJ (eds): ILSI Press, Washington DC, pp. 130-16.

Stevenson DG, Eller FJ, Wang L, Jane J-L, Wang T, George E, Inglett GE. 2007. Oil and tocopherol content and composition of pumpkin seed oil in 12 cultivars. J. Agric. Food Chem. 55, 4005-4013.

Tan DT, Khor HT, Low WH, Ali A, Gapor A. 1991. Effect of a palm-oil-vitamin $\mathrm{E}$ concentrate on the serum and lipoprotein lipids in humans. Amer. J. Clinic Nutr. 53,1027S-1030S

Theriault A, Wang Q, Gapor A, Adeli K. 1999. Effects of $\gamma$-tocotrienol on apoB synthesis, degradation, and secretion in HepG2 cells. Arterioscler. Thromb Vas. Biol. 19, 704-712.

Tietz NW. 1976. Fundamentals of Clinical Chemistry, W.B. Saunders, Philadelphia, pp. 299.

Turner JD, Le NA, Brown WV. 1981. Effect of changing dietary fat saturation on low-density lipoprotein metabolism in man. Amer. J. Physiol. 241, E57.

U.S. Food and Drug Administration. 2000. Code of Federal Regulation No. 83- 000. Food Labeling: Plant Sterol / Stanol Esters and Coronary Heart Disease.

Vanstone CA, Raeini SM, Parsons WE, Jones PJ. 2002. Unesterified plant sterols and stanols lower LDL cholesterol concentration equivalently in hypercholesterolemic persons. Ann. J. Clin. Nutr. 76, 1272-1278.

Yang B, Karlsson RM, Oksman PH, Kallio HP. 2001. Phytosterols in sea buckthorn (Hippophaë rhamnoides L.) berries: Identification and effects of different origins and harvesting times. J. Agric. Food Chem. 49, 56205629 . 